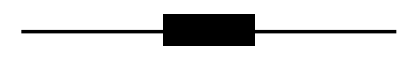

\title{
Introduction
}

\section{One Hundred Years of Anthropology of Religion}

One could say that in 2012 the scientific study of religion, particularly in its anthropological form, has become one hundred years old. In 1912, Durkheim published The Elementary Forms of Religious Life, perhaps the most influential book in the social study of religion, and certainly in the anthropology of religion, of the entire twentieth century. But this was not the only seminal work published around a century ago. A little earlier than that, in 1909, Arnold van Gennep's Les rites de passage inaugurated an interest in liminality and ritual that has accompanied our discipline ever since. That same year, Marcel Mauss wrote La prière, an unfinished thesis that started an equally unfinished interest in prayer, one of the central devotional practices in many religions across the globe. In 1910, Lévy-Bruhl published his first explicitly anthropological book, How Natives Think, a problematic ancestor of a debate about rationality and modes of thought that has accompanied anthropology and philosophy ever since. In 1913, Freud tackled the then fashionable topic of totemism in his Totem and Taboo. Around those early years of the century, too, Max Weber was starting to write about charisma, secularization, and rationalization, topics of enduring interest.

Looking at that effervescent turn of the century from today's perspective, we might say that the anthropological study of religion ages well, weaving today's approaches and preoccupations with structuring themes that have been inherited from our founders. The main areas of the anthropology of religion that were present at the turn of the last century are alive and kicking at the turn of the twenty-first. Tylor's intellectualism and Lévy-Bruhl's preoccupation with rationality are echoed by today's cognitive anthropology of religion (a field already explored in previous volumes of this journal). Durkheim's emphasis on moral integration is echoed by innovative studies exploring the relationship between religion and moralities. Even the diffusionists, whom we thought we had debunked at some point, are echoed by scholars with a growing interest in migration and in what we could perhaps call the transnational structures of religious life. The first hundred years of anthropology of religion closes upon itself, almost like a perfect circle, although in fact it is a spiral, always growing and richer than before.

This volume of Religion and Society: Advances in Research is a good indicator of the healthy state of our discipline a century after it got underway. As explained in the introduction to volume 1, this is not an anthropological journal per se (in volume 2 we portrayed a sociologist of religion and debated a book written by a political scientist), but we try to keep anthropology as the root discipline from which to reach out to other ones. Maybe because the centenary of Durkheim was at the back of our minds when we started commissioning articles for it, volume 3 has turned out to be particularly anthropological in its themes and authors. Our guest authors have combined their preoccupations with a solid tradition that took off a century ago and that is still being thought through in our classrooms, as James Bielo discusses in his piece on keeping the classics alive in teaching the anthropology of religion. Paul-François Tremlett delivers a timely 
article exploring issues of community, politics, and morality in the Occupy movement in London. Beginning with reflections on the work of our portrayed author (Jean Comaroff) relating to the neo-liberal situation, Tremlett works through the Occupy case study by evoking and invoking Durkheimian notions of moral community and sacralization of society. He discusses mobilization and territorial imagination while simultaneously making a more Weberian link between religion and economy, albeit through the lens of a secular movement that seeks to contest pragmatic realities by promoting utopias.

By thoroughly reviewing a selection of recent texts, Allen Abramson and Martin Holbraad also inscribe themselves into an almost forgotten tradition of cosmological studies, convincingly showing that 'cosmology', which some authors would have considered an awkward category from the past, may still in modified form be a very useful tool to help us understand the world in which we live, and not just an obscure reification of other people's worldviews. We could twin this review article with the one produced in volume 1 on Amazonian cosmologies by Luiz Costa and Carlos Fausto (see, incidentally, the caution against the increasing trend in 'ontology' approaches that Peter Geschiere provides in his comment on Jean Comaroff's work in this volume).

Thomas Carter explores the somewhat counter-intuitive links between religion and sport and how they have been studied by social scientists. Whether or not sport is a form of (secular?) religion may involve a question of definitions, but no doubt the symbolism and ritualization with which it is surrounded should be of interest to anthropologists and religionists. Carter is aware of the dangers of external categorization (where does religion end and sport begin?) but offers an analysis dissecting the empirical and conceptual underpinnings of his topics: the historicity of the sacralization of sport, the way that religion studies scholars have looked at sport, the way that sport scholars have looked at religion, and, more generally, the way that anthropologists have approached game, play, and sport-'transcendental practices' that can be tackled from different perspectives.

Keeping alive the anthropology of tropes and of irony, Michael Carrithers offers an insightful reflection on hyperbole and sacredness as idioms through which problems of memory and identity become explicit. Using the dramatic case studies of $9 / 11$ and the Holocaust, he argues for an 'ironic anthropology' that may become much more fruitful in order to understand 'serious' and 'hyperbolic' religious contexts. He sees sacredness itself as one such form of hyperbole.

Several articles in this volume explore the transnationalization of religion (and in that respect they respond to the 'spatial turn' in the study of religion pointed out by Kim Knott's seminal piece in volume 1 of Religion and Society). Paul Johnson elaborates a thorough review of the relationship between religion and diaspora, while Roger Sansi and Luis Nicolau Parés take us to Brazil to investigate the cultural logics behind Afro-Brazilian cults and to review the debates that this religion has originated on issues of both territory and historicity. In a similar transnational vein, and with overlapping territories, Paula Montero reviews debates about missionaries and anthropology on both sides of the Atlantic, exploring the similarities and differences behind the regionalized historiographical literature that debated mission in Africa and America. Through a discussion of tropes such as 'encounter', 'translation', 'mediation', and 'agency', she seeks to establish a common agenda that may prove relevant for a wider conception of an 'anthropology of missions'.

Many of the debates mentioned above-transnationalism, anthropology of mission, neoliberalism-have characterized a great deal of the work of Jean Comaroff, undoubtedly one of the most important voices in the anthropology of religion over the past 30 years and the author whom we portray in this volume.

Our debate section takes us to another interesting development in the anthropology of religion: the place and role of religion in revolutionary contexts. This has become an increasingly notorious theme in public debates, especially since the Egyptian revolution and the emergence of 
what has often been referred to as 'Tahrir politics'. In this volume, however, we decided to open the scope and invite scholars working on different historical and empirical contexts to contribute their own reflections, rendering complex the apparent exceptionalism behind the Egyptian case. The outcome is a set of pieces with diversified approaches and theoretical configurations. Sidharthan Maunaguru and Jonathan Spencer describe current developments in the Tamil conflict and their efforts to account for the internationalization of the insurgency, working in two sites of confrontation separated by several thousand miles: Eastern Sri Lanka and North London. Their case study, in sharp contrast with contemporary revolutions, extends throughout decades and generations, exploring successive processes of religious involvement and reconfigurations within the struggle. Charles Lindholm debates an old issue-jihadism-exploring its implicit historicity and seeing it as structuring attempts to resurrect the 'sanctified community' lost after Muhammad's death. His analysis suggests more continuities than one normally would associate with notions of 'radicalism', 'fundamentalism', and so on. In sharp contrast with this past-oriented structural continuity, Mark Juergensmeyer moves beyond Tahrir and questions the 'future of religious rebellion', interrogating international political developments and their conflation within religious movements.

Finally, the section "An Author Meets His Critics" scrutinizes Manuel Vásquez’s More Than Belief, a book that picks up long-standing debates in the study of religion, bringing together issues of practice, belief, materiality, and cognition in an innovative way. The lively dialogue between the author and his critics in this section clearly proves that a multi-polar approach to religious practice can be more fruitful than sticking to the strict observance of a particular school or scientific approach.

All in all, the anthropological study of religion continues to be as lively today as it was in its early days a hundred years ago. Anthropologists of religion, working in close collaboration with other scholars of religion, evoke our ancestors while reaching broader horizons and discovering unexpected connections between topics, authors, regions, and traditions. The spiral keeps growing. May we live another hundred years.

Ramon Sarró, Simon Coleman, and Ruy Llera Blanes 


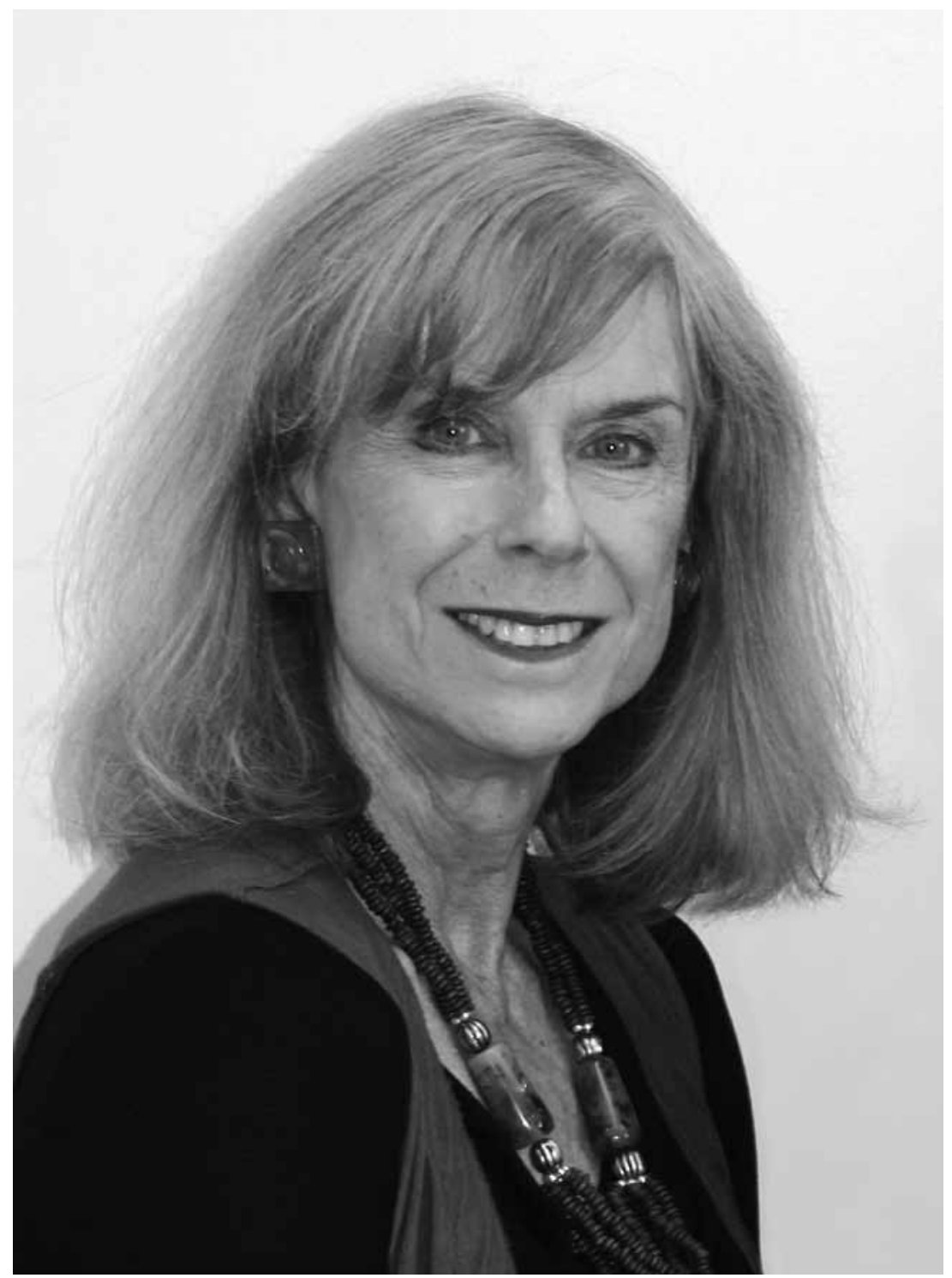

Jean Comaroff 